\title{
Politeness Strategies of the Provisional Agreement Document
}

\author{
Mohammad Shehadeh \\ Hail University, Saudi Arabia \\ E-mail: muhammad.ababneh@yahoo.com
}

Doi:10.7575/aiac.alls.v.8n.1p. 227

Received: 05/12/2016

URL: http://dx.doi.org/10.7575/aiac.alls.v.8n.1p.227

Accepted: 22/02/2017

\begin{abstract}
This work investigates the politeness strategies of the so-called provisional agreement document in Jordanian context. It shows that such a document maintains several politeness strategies that help resolve any tension between the parties involved. It reflects that politeness is not meant only to elevate the communication between people but also it is an important clue in cataloguing this communication when it occurs in situations where the relationship between the two interlocutors is doomed by tragic event such as murder or car accidents.
\end{abstract}

Keywords: Politeness strategies, agreements, Jordan

\section{Introduction}

The provisional agreement of intent for tribal reconciliation or the so called (Patwah) is a traditional practice that occurs in social contexts during the course of everyday life. This line of agreement as such starts when a problem arises between two or more different tribes. The perpetrator's family resorts to a tribe chief who belongs to a different tribe and asks him to intermediate between the conflicting parties to settle up the conflict. The problem starts when a car accident occurs and results in casualties either when two cars collide with each other, or when a car runs over someone. Thus, the process of reconciliation commences when the perpetrator or his family seeks (?ațah) via a well-reputable mediator from another tribe and asks him to intermediate between the two dissenting parties to settle down the conflict. Traditionally, if the perpetrator does not seek (( Rațah) during three and one-third days, the so called "outburst of blood period" of committing the felony, he loses the right of being protected and defended by a third party tribe and hence is considered guilty in pursuant to tribal jurisdiction.

The perpetrator guarantor or the so called (Șa:hib ?al-wadłah) makes his primary contacts with the victim's tribe to introduce himself as an interlocutor. The victim's family or tribe may accept or refuse any mediation ${ }^{\mathrm{i}}$. In this case, the interlocutor may resort to famous mediators to have assistance in the course of primary phases of negotiating reconciliation. Besides, the victim's clan may refuse a certain interlocutor to intermediate between them and the perpetrator's tribe, so the offender's family must search for another interlocutor. Al- Oudat (2005: 53) mentions “in choosing the participant in peacemaking process, the mediator looks for influential individuals with relationships to the victim group, since they usually use their standing to reduce the amount of the money settlement".

The delegations (dza:hah) ${ }^{\mathrm{ii}}$ gather in the diwa: $\mathrm{n}^{\mathrm{iii}}$ or tent of the perpetrator's tribe and head for the (diwa:n) or tent of reconciliation which has been prepared by the injured party. Black coffee is served before the leader of (dza:hah) who in turn refrains from having the cup of coffee till they obtain the approval to conduct the provisional agreement document and follow all the procedures of peacemaking. Meanwhile, the victim's family usually asks for an unaffordable amount of money especially in severe cases like killing, manslaughter and heavy casualties. In this connection, the role of the delegation predominantly emerges to trim down that huge sum of money. Actually, the delegation follows certain convincing strategies associated with religion, the loyalty for the king, and, of course, the traditional law. More concretely, the delegation asks the victim family to lower the amount of money in question for the sake of Allah, then for the sake of the king and esteemed gentry. As a result, the dissenting parties may reach an agreement between them and write it down in the form of a reconciliation decree.

Short-term agreement is of importance in tribal Arab jurisdiction for many considerations. Indeed, if the family of the victim agrees on giving (?ațah), it usually implies that they are giving their preliminary consent for the eventual peacemaking. It aims at preventing the victim's family from taking revenge on the perpetrator or his family or patrilineal relatives, resolving the problem, tightening the spot of dispute and making peace. Al-Tal (1997:255) delves into the gravity of the provisional agreement. He mentions that (?atwah) aims at reducing disputes, hostility and conflict, preventing the victim family from taking revenge on the offender, and making peace in the society. Besides, he states that (?atwah) gives the perpetrator's family a chance to change their place of living especially in severe crimes. Nevertheless, changing the place of living does not imply that the offender will escape with his crime, but it bans the victim's family from any illegal actions against the perpetrator or his family until enforcing the civil or tribal law. Broadly, the provisional agreement of intent is a mechanism to support the official law in Jordan. 
So, the questions that arise here include to what extent the provisional agreement document follows Grice's maxims and what are the most frequent politeness strategies of both the interactions and documents of the provisional agreement. The discussion to follow is dedicated to answering this question. Before that, I mention the types of provisional agreement of intent for concreteness.

\section{Types of Provisional Agreement of Intent}

Abo-Khawsah (1993: 50) mentions six kinds of provisional agreement and specifies that provisional agreements are different from each other in terms of duration and procedures according to the severity of the crime:

- (?ațah) of Police: This kind of (?ațah) occurs in severe cases like manslaughter, killing cases, and crimes of passions. It lasts three days and third. It is called (?ațah) of police since it is given by policemen who interfere to impose peace.

- (?atwah) of concession: This type of (?atwah) is granted by the family of the victim to that of the offender in which the offender admits committing his offense and he is all set to give the victim's rights.

- Denial (?atwah): It means that the offender denies the crime in question. In this case, the disputants have to appeal to a tribal judge.

- (?atwah) of Approach: It is usually conducted after the tribal judge reaches a verdict. Peacemaking is usually conducted during the last three days of this (?atwah).

- Deficient (?atwah): A criminal is not included in this (?atwah), so he is considered tribally wanted by the conflicting parties.

- Honors (?atwah): It is assigned to crimes of passion and violating the properties. It guarantees that the offender has to be punished.

\section{Review of related literature}

In this section, I review some literature which tackles similar phenomena.

Stein, et al. (1997:233) investigate the ways in which two persons resolve difference in opinions during an argument. They also describe the conflict talk associated with different argument outcomes; they divide the participants in terms of argument outcomes into three categories, a win-loss, standoff, and compromiser. They (1997:259) conclude that without compromise instructions men and women negotiate compromises only $37 \%$ of the time given to talk, while they negotiate compromises $57 \%$ of the time with the compromiser instructions. Their study has implications for other researchers' findings. They show that when men and women choose to end their negotiation in a win-loss, women almost always win. They show that this finding, however, is incompatible with Gilligan's (1982) and Tonnen's (1990) notion that females compromise more with males and do not win negotiations. It should be noted that the present study differs from the previous study in one main perspective. In fact, the present study is oriented toward analyzing the speech acts of the provisional agreement, whereas the former loosely deals with the process of understanding and resolving conflicts.

Kangasharju (2002: 1448) expands on the alignment in disagreement in the course of committee meetings. She demonstrates that alliances are typically formed after matter-of-fact statements, stance-takings, and proposals which call for disagreement. The common devices, she adds, used in the first alignment turns are collaborative completion and repletion of the elements of the prior turn. Kangasharju's article shows that alliances achieve four main kinds of tasks in the committee meeting interactions. First, alliances correct statements on the basis of the participants' knowledge. Second, they function as a controlling organ in that they adjust one-sided stance expressed by a co-participant. Thirdly, they are set up in the process of making decisions. Finally, performing in alliance can be rewarding for the members as a social position.

Saft (2004:543) investigates contexts for arguing in Japanese university faculty meetings. His study focuses on turntaking organizations used by faculty member participants in two meetings. These turn-taking organizations, in fact, are used to show how talk in one set of meetings is designed to facilitate the onset of argument, while talk in the other set is constructed to discourage participants from exchanging statements of the oppositions. He adds that the organization of talk in the meeting is essential to institutional work used by participants. Saft (2004:551) argues against some Japanese scholars who suggest that the need to maintain harmony and hierarchy prevents Japanese from expressing opinions freely and engaging in activities such as complaining, disputing and arguing.

Al-Qudah (2009) expands on the sociolinguistic functions of exchanged speeches in light of politeness strategies. In his work, Al-Qudah endeavors deeply to probe into the marital engagement, one of the most important Jordanian tribal traditions, as well as its etiquette expressions. This study provides an impression about some happiness procedures in North Jordan and comes up with linguistic components like agreeing, requesting and complimenting. These linguistic components, in fact, constitute linguistic etiquette norms. Besides, sociolinguistic and sociocultural factors like wealth and level of education affect the process of selecting the interlocutor. The present work, however, is different from that of Al-Qudah in more than one perspective. Firstly, some of the politeness strategies that are used in the interactions of the marital engagement are different from those used in the provisional agreement. For instance, the apology strategy is mainly used in the speech delivered in the provisional agreement, while this strategy cannot be utilized in that of the 
marital engagement. Secondly, the researcher in the present work will investigate the written documents in the provisional agreement, whereas Al-Qudah does not study the document that might be potentially conducted through the process of the marital engagement.

This overview clearly reveals that there are no studies that have dealt with the provisional agreement of intent for caraccident tribal reconciliation in North Jordan. This study, thus, is intended to fill the gap in the area of sociolinguistics and anthropology and to provide us with a linguistic account of this provisional agreement.

\section{Data analysis ${ }^{\mathrm{iv}}$}

Having studied the documents of provisional agreements, the researcher finds that most of the documents have the same formula with a subtle difference between them since they all tackle the same crime, namely, car accidents. Nevertheless, this part is mainly dedicated to investigate the provisional agreement documents from both sociolinguistic and pragmatic points of view. To be clear, the proper effect of these documents is achieved by formulating appropriate expressions suitable to the situations as such. In this connection, they have the effect of positive attitudes towards the afflicted person or his family. This effect can account for the fact that the delegation pays a visit to convince the afflicted party to agree to conduct the provisional agreement. If one wrongly supposes that provisional agreement does not have any phatic dimension, then there will be no principled account of the role of the delegation in this process. In fact, the delegation aims at enhancing the situation of the afflicted party before other tribes in North Jordan. Enhancing the situation is carried out both by paying a visit to the afflicted party's guesthouse and by expressing politeness strategies. Therefore, the written expressions of a provisional agreement involve politeness strategies of human relations that may in general fulfill the intent. The researcher finds out three pragmatic strategies shared by most of the provisional agreement documents. These strategies are thanking, praising and loyalty.

\subsection{Thanking}

Thanking is a very important strategy exchanged through the provisional agreement document. Actually, this strategy is maintained as a reaction of agreeing to conduct the decree. It seems that there is a kind of exaggeration through expressing this strategy in the provisional agreement document. This exaggeration can be deduced by using the same expressions: (karam Sarabi: ?aȘi:1, hoson astiqba:lihim). Even though the receiving party may not show high generosity and hospitality in all cases, the delegation exaggerates thanking owing to the fact that the offender's fate is determined by the victim's family. More obviously, the delegation warmly thanks the receiving party for their generosity and hospitality even though the receiving party may not be as generous and hospitable as what is expressed by the following example.

At the end of the decree, the delegation thanks the receivers. Consider the following example:

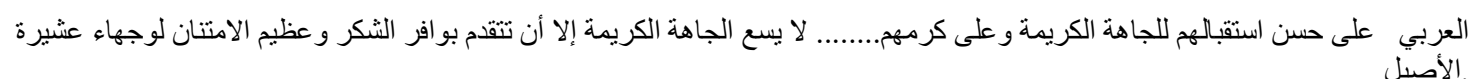

la: yasaS adz-dza:hah ?al-kari:mah ?il-la: ?an-n tataqaddam biwa:fir ?f-fokor wa@aĐi:m ?al-?imtina:n liwodzaha?

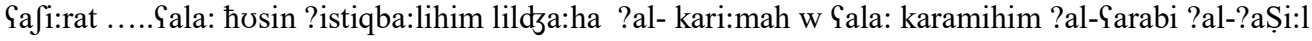

The esteemed gentry has nothing to do but to acknowledge debt and express their gratitude to the dignitaries for their warm reception and hospitality.

As a result, the provisional agreement decree shows plentiful politeness which is important for the resolve the tension between the two parties (see, Taha et al 2014, Al-Jarrah et al 2015, and Jarrah 2016 for further discussion on how words can be used to clear tension and safe face.)

\subsection{Praising}

In some provisional agreement documents, the delegation praises the victim's family for the consent given to conduct the provisional agreement document:

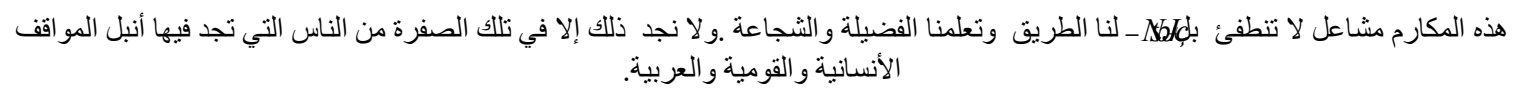

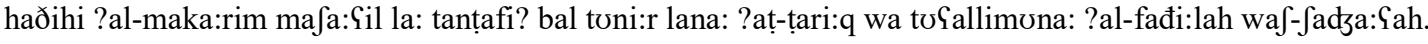
wala: nadłid ða:lik ?il-la: fi: tilka: ?aṢ-Șafwah min ?an-na:s ?al-la:ti taḑ̇id fi:ha ?anbal ?1-mawa:qif ?al?insa:niyyah wal-qawmiyyah wal- arabiyyah

Those noble deeds are flames which light the way and teach us courage and virtue. We only find this in the elite people with human, national and Arab stands.

It sounds very clear that the interlocutor is very polite in conducting this decree. This politeness is present by using the lexical word (?aȘ-Ṣafwah) "elite". He metaphorically considers the act of giving the provisional agreement as lanterns which do not turn off and light our way. However, it is plausible that the interlocutor keeps exaggerating in praising the receiving party. Exaggeration is present by repeating the same expressions in all documents the interlocutor conducts. He mentions that a provisional agreement of intent teaches us how to be courageous, but one thinks that giving a provisional agreement does not always need that courage in all cases of car accidents. 
Exaggeration in praising the victim party is very functional at this stage of reconciliation. ${ }^{\mathrm{v}}$ This agreement is only temporary and peace-making is not still conducted, so exaggeration in the praising process is a linguistic mechanism to reach peace-making among the dissenting parties. That is, the gentry exaggeratedly praise the victim's party in order to convince the victim's family to agree on peace-making which is the ultimate goal of the provisional agreement of intent. Thus, reaching peace-making entails the delegation to be very polite in this document.

4.3 Loyalty

The politeness strategy of loyalty is present in the provisional agreement documents. The formula of loyalty is almost always formalized in the following statement:

$$
\begin{aligned}
& \text { اكر اما لله و الوطن و الملك ..... وقد تم الاتفاق على اعطاء عطوة لمدة. } \\
& \text { waqad tamma ?al-?ittifaq Sala: ?iৎța:? Gațwah limuddit.....?ikra:man lila:h wal-wațan wal-malik. } \\
& \text { We hereby agree on the provisional agreement for...... for the sake of Allah, state and king. }
\end{aligned}
$$

This statement represents the Jordanians' doctrine; i.e., their loyalty is devoted to Allah, the state and the king. Being a member of the Jordanian society, the researcher thinks most of Jordanians have loyalty to their religion, "Islam and Christianity" and their king, Abdullah II. This finding could be illustrated by the fact that all of the provisional agreement documents the researcher collected have the above statement. It is plausible that the afflicted party does not exaggerate in expressing the reason why they give a provisional agreement. The lack of exaggeration is observed in the structure of the above mentioned example. That is, the writer mentions Allah first, then state, then king. If the afflicted party structurally mentioned the king first, they would exaggerate in expressing their loyalty to the king. This result is represented in Islamic teachings that all of Muslims' deeds must be devoted to Allah.

Consider this formula of loyalty:

$$
\text { اعطاء عطوة اكر اما لله ورسوله و الملك المفدى والجاهة الكريمة على ..... تكرمت عشيرة. }
$$

takarramat Gafi:rat......?ikra:man lilla:h warasu:lah wal-malik ?al-mofadda wadł-dza:hah ?al-karimah Gala: ?iSṭa:? Sațwat

Tribe........generously gives a provisional agreement for the sake of Allah, his prophet, glorious king and esteemed gentry.

This expression supports our claim that the afflicted party does not exaggerate in their loyalty. In this example, they mainly concentrate on their loyalty to religion. This fact is illustrated in the structure of that statement; they first mention Allah and his Prophet, and then the king and esteemed gentry (see, Hammouri et al 2013 for similar analysis).

In a nutshell, Jordanians are loyal to Allah, state and kind. This result is illustrated by performing the act of loyalty in the entire provisional agreement documents the researcher collected from different areas of North Jordan. In addition, no exaggeration seems to be in expressing loyalty since the afflicted party word their approval to conduct the provisional agreement by first stating Allah as a first reason of their approval, then the state, and then the king.

Our next task is to show where the provisional agreement document considers Gricean maxims, the task I take up in the following section.

\subsection{Gricean Maxims and the Provisional Agreement Document}

The pertinent question is "Do the provisional agreement documents in North Jordan observe Grice's cooperative principle?" (Grices's maxims are quoted in Leech(1983:17)).

The first maxim of quantity is to give the right amount of information; the document must be as informative as required. After precisely examining the amount of information, the researcher finds that most of these documents are one page and no superfluous constituents are present in these documents.

The maxim of quality entails adequate evidence concerning the incident; i.e., the formula of the document does not lack adequate evidence. The content of this document is maintained to express truthful incidents. This point is illustrated in the following examples:

$$
\text { مؤمنه ومرخصه .... رقم .....الذي يسوق سيارة نوع ............ توجهت الجاهة الكريمة الى ديوان عشيرة...... في يوم }
$$

fi: yawm....tawadz-dzahat adz-dza:hah ?ila: diwa:n Gafi:rat........?alla:ði: yasu:q siyya:rah

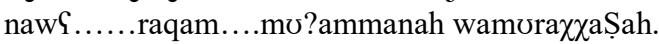

On ........... the esteemed delegation heads for the X's guesthouse...... who drives the car whose brand is... and its legislation number is ......insured and licensed.

These details are functional in the provisional agreement documents. Stating these deliberate details has something to do with the insurance company, on the one hand, and the police, on the other hand. Consider the following example:

$$
\text { لا مانع من اخلاء سبيل السائق ..... }
$$

la: ma:niৎ min ai $\chi$ la:? sabi:1 ?as-sa:?iq....

We do not mind releasing the driver ..... 
The statement indicates that the police can set free the doer of the accident "driver" on the strength of what is stated in the provisional agreement document. However, insurance companies maintain some details concerning the car accidents, so the document in general accomplishes the adequate evidence requirement by mentioning details related to the type of the car in question, its registration number and the state of the car in being licensed covered against car accidents or not. In a nutshell, we can conclude that the provisional agreement document maintains the maxim of quality by stating adequate pieces of evidence about the car accident involved.

Leech (1983: 84) states that the maxims of quantity and quality both can be interdependent; the amount of the information the speaker or writer gives is limited by their wishes to avoid telling lies. By virtue of the fact that most of the provisional agreement documents are mainly one page, it indicates that the writers "usually the interlocutor and truce guarantor" of the provisional agreement decree first avoid digression that may lead to controversial opinions and second stating untruthful facts related to the incident itself. In addition, the writers, although repetition is functional in some contexts, do not repeat or paraphrase any of the previously mentioned examples, precisely because the sentences are indicative. This result gives rise to the fact that the maxim of quality and quantity both are almost met in the provisional agreement document.

The maxim of relation "be relevant" has received great interpretations among linguists like Leech. The provisional agreement document is considered relevant to a speech situation if it can be interpreted as contributing to its goals. Discussing the maxim of relation entails exploring the speech delivered in the provisional agreement negotiations to discover the relation between what is offered and what is replied. The interlocutor offers in the negotiation:

$$
\text { احنا مستعدين للي بدكم اياه. }
$$

?iћna: mustaSiddi:n lalli: badkum ?iyya:h

We are ready to do whatever you want.

The answer written in the provisional agreement document is:

$$
\text { ل الا مانع من اخلاء سبيل السائق. }
$$

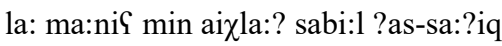

\author{
We do not mind releasing the driver from prison
}

The connection between the interlocutor's offer and the injured party's reply is very simple. It does not show any indirectness in offering or replying. That connection is owing to the fact that the incident itself is a sad occasion and the perpetrator's family are on tenterhooks to conduct the provisional agreement and to get an approval to set free their son who is in prison. Therefore, offering comes to be as direct as possible. On the other hand, the state of the afflicted family, being very sad, obliges them not to use indirectness in replying. It is clear that the maxim of relation is met in the provisional agreement document as a relation to what is offered and replied in the course of the provisional agreement negotiations.

Finally, the maxim of manner can be illustrated in the provisional agreement via making unambiguous structures of the language in order to construct a clear text. Leech (1983: 100) believes that a negative sentence provides evidence for the independent role of this maxim. He considers negative sentences pragmatically less favored than positive ones because they are less informative than their positive counterparts:

\title{
Ali was run over by Sami.
}

Ali was not run over by Muhammad.

The number of people who run over Ali in the negative sentence is much greater than the number of people in the positive sentence. Although the two sentences are completely true, this maxim entails avoiding the negative sentence whenever the positive sentence can be used in its place. ${ }^{\mathrm{vi}}$

Consider the following examples:

$$
\text { و افق أهل المصاب على اعطاء عثيرة س عطوة عشائرية. }
$$

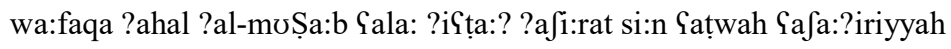

The afflicted party hereby agreed to give tribe $X$ a tribal provisional agreement.

$$
\text { لم يو افق أهل المصاب على اعطاء عشيرة ص عطوة عشائرية. }
$$

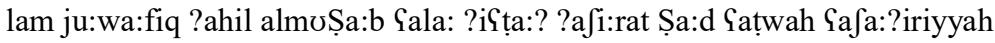

The afflicted party did not hereby agree to give tribe $Y$ a trial provisional agreement.

Even though these two sentences are true, the afflicted party agrees to give a provisional agreement to tribe $X$, whereas tribe Y does not need a provisional agreement since no one of that tribe commits any offensive behaviour. Since the provisional agreement documents do not use the negative counterparts of positive ones, we can conclude that the maxim of manner is met in the provisional agreement document.

To sum up, provisional agreement documents are most likely to follow Grice's maxims of quantity, quality, relation and manner. 


\section{Conclusion}

This research shows that the most frequent strategies of the decree are thanking, praising and loyalty. Even though interlocutors seem to be very polite in thanking the afflicted party, they exaggerate thanking. Exaggeration in praising the afflicted party is functional in the provisional agreement since it is a linguistic mechanism to reach peacemaking. Additionally, this research finds out that the document is likely to follow from Grice's four maxims. That is, the document maintains the maxims of quantity, quality, relation and manner.

\section{References}

Alhaisoni, E., Jarrah, M.A. and Shehadeh, M.S. (2012). An investigation of evidentiality in the Arabic language. International Journal of Linguistics, 4(2), pp.260-273.

Al-Jarrah, R.S., Abu Dalu, A.M. and Jarrah, M. (2015). A relevance-theoretical account of three Arabic pragmatic operators of concession in a political discourse. Lodz Papers in Pragmatics, 11(1), pp.51-76.

Al-Qudah, M. (2009). A Socio-pragmatic Study of Speech Exchanged on Marital Engagement Occasions in North Jordan. Unpublished M.A. thesis, Yarmouk University, Irbid, Jordan.

Al-Oudat, M. (2005). Tribal Identity and State Power. German: Shaker Verlag.

Gilligan, C. (1982). In a Different Voice: Psychological Theory and Women's Development. Cambridge, Mass.: Harvard University Press.

Hammouri, Y.M., Jarrah, M.A. and Khawaldeh, S.K. (2013). Intertextuality as a tool to determine syntax. International Journal of Linguistics, 5(2), p.209.

Jarrah, M.A. (2016). Explicit-implicit distinction: A review of related literature. Advances in Language and Literary Studies, 7(1), pp.175-184.

Jarrah, M.A., Alhaisoni, E., Hammouri, Y.M. and Shehadeh, M.S. (2013). A Semantico-Phonological Investigation of Proper Nouns. International Journal of Linguistics, 5(3), pp.1-20.

Jarrah, M. and Zibin, A., (2016a). On Definiteness and Information Trigger in Arabic. Advances in Language and Literary Studies, 7(2), pp.55-67.

Jarrah, M. and Zibin, A. (2016b). Syntactic investigation of nunation in Haili Arabic. SKY Journal of Linguistics, 29, pp.39-62.

Kangasharju, H. (2002). "Alignment in Disagreement: Forming Oppositional Alliances in Committee Meetings". Journal of Pragmatics, 34, 1447-1471.

Leech. G. (1983). Principles of Pragmatics. London: Longman.

Saft, S. (2004). "Conflict as International Accomplishment in Japanese: Argument in University Faculty Meetings". Language in Society, 33(4), 549-584.

Stein, N., Bernas, R. and Calicchia, D. (1995). "Conflict Talk: Understanding and Resolving Agreements". In Givon, T. (ed.). (1997). Conversation: Cognitive, Communicative, and Social Perspectives. Amsterdam and Philadelphia: John Benjamins Publishing Company. p.p.: 233-267.

Taha, K., Jarrah, M.A. and Al-Jarrah, R.S. (2014). The discoursal Arabic coordinating conjunction wa (and). International Journal of Linguistics, 6(4), p.172.

Tannen, D. J. (1990). You Just Don't Understand: Women and Men in Conversation. New York: Willam Morrow.

$$
\begin{aligned}
& \text { التل، غسان .(1997) .الصلح العثائري بين النظرية و التطبيق .عمان رمطابع المؤسسة الصحفية . }
\end{aligned}
$$

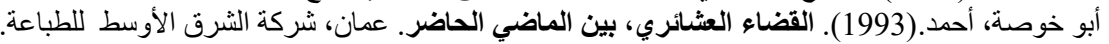

\section{Notes}

\footnotetext{
${ }^{\text {i }}$ Abo-Khawsah (41:1993) says that (?al-wadzah) means a sudden truce and it is said to prevent a strike at the moment of saying : for the sake of sheikh x and his tribe (عليهاوجه الثيخ فلان وعشيرته). He adds that both conflicting parties must comply with this sudden truce; otherwise, they would lose their rights in tribal jurisdictions.

ii (dza:hah) is a group of people who can affect the victim's family due to their rapport and camaraderie to conduct the provisional agreement document.

iii (diwa:n): A huge hall which is assigned to discuss the tribe's affairs, receiving adolescence and celebrate marital engagement and wedding.

iv As for data collection, the researcher interviewed twelve experienced interlocutors from Irbid, Jarash, Ajloun and Mafraq. Because the majority of the population is found in Irbid, about one million, six interlocutors were interviewed from Irbid and two interlocutors were met from the other mentioned cities. After that, six interlocutors were randomly chosen for the purpose of the study. Likewise, three interactions were taken from each of the above mentioned cities.

${ }^{v}$ Another manifestation of exaggeration in parsing the victim party is the use of the definite article in almost all nouns; this is to imply that, for instance, the agreement that is reached is genuine and unique (see, Jarrah et al 2013 and Jarrah and Zibin 2016a,b for further discussion of the use of the definite article).

${ }^{\mathrm{vi}}$ It is observed that verbs occur much in this type of agreement. I interpret this following the lines of Alhaisoni et al 2012 that the past form of the verb is used to show high levels of evidentiality and thus respect.
} 